\title{
地域における在宅介護サービス供給に関する基礎的研究 A FUNDAMENTAL STUDY ON HOME NURSING SERVICE SUPPLY FOR ELDERLY IN LOCAL DISTRICT.
}

\author{
泉 恵 太*, 石坂 公一**, 近江 隆*** \\ Keita IZUMI, Koichi ISHIZAKA and Takashi OMI
}

\begin{abstract}
In this paper, a potentiality of home nursing service supply for elderly, is examined from a point of private company business management in the local district.

The result is as follows:

1. From a point of business management, numbers of nursing the service user and their spacial distribution have large influence on the profit balance of a service supplier.

2. In Miyagi prefecture, there are some cities and villages in which home nursing service can't be supplied by private company because of their profit balance.

3. The enlargement of service supply area and concentration of user have some effect to improve business condition of home nursing service supply.
\end{abstract}

\section{Keywords: home nursing service, business management, local district, elderly, profit balance} 在宅介護サービス、事業採算、非都市地域、高齢者、経営評価

\section{1. 研究の背景と目的}

我が国では急速な高齢化を背景に、高齢者保健福祉の分野におけ るサービスの総合的な整備・推進が図られており、中でも高齢者が 可能な限り住み慣れた家庭や地域で暮らせるよう在宅福祉サービス 辣1) (以下、在宅サービス) の拡充が求められている。しかし、在宅 サービス事業は、運営に要するコストのうち、移動コストや人件費 等の直接経費の占める割合が多く、一般に人口の少ない過疎地等で は採算の確保が容易でないとされており、そのような地域でのサー ビス供給が課題となっている。

そこで、本研究では、移動コスト等諸要因を考慮した在宅サービ ス事業主体の経営評価モデルを作成し、地域における在宅サービス の供給可能性について事業採算面からの分析を行うとともに、地域 レベルでの在宅サービスの在り方について検討することを目的とす る。具体的には、経営評価モデルを用いた仮想地域でのシミュレー ションから在宅サービスの事業特性を把握するとともに、宫城県内 6 自治体を対象としたケーススタディにより、実際の市町村での事業 採算性に関する検討を行う。

なお、本研究では、在宅サービスの中で中心的役割を担っている 訪問介護部) (ホームヘルプサービス) 事業を対象として分析を行う。

\section{2. 在宅サービス事業の経営評価モデル}

2. 1 概要

\section{- 基本仮定}

在宅サービス事業の経営評価モデルにおける基本的な仮定を以下． に示す。

・事業主体の扱うサービスは訪問介護のみとする。

・事業主体の事業展開範囲は、仮想地域内（ケーススタディでは、 市町村域内）とする。

- 収入項目は介護報酬のみとし、補助金等の補助的収入は含めない。 また、介護報酬の加算・減算項目は原則として考慮しない范3)。

- 事業展開地域は $1 \mathrm{~km} \times 1 \mathrm{~km}$ メッシュに区分され、サービス利用者 はいずれかのメッシュに居住するものとする。

・ 1 訪問当たりのサービス提供時間は、 0.5 時間、 1.0 時間、 1.5 時間 の 3 種を設定し、所定のサービス提供時間割合に基づいてメッシ 乙単位でサービス提供時間を割り当てる。

・提供サービスは、身体介護、生活援助及び両者の組み合わせの 3 種を設定し、所定の提供サービス割合に基づいてメッシュ単位で 提供サービスを割り当てる。

- 経黨評価モデルの流れ

経営評価モデルの概要は以下の通りである。
* 世田谷区 工修

** 東北大学大学院工学研究科都市建築学専攻 助教授・工博

****東北大学大学院工学研究科都市建築学専攻 教授. I博
Setagaya Ward, M. Eng.

Assoc. Prof., Dept. of Architecture, Univ. of Tohoku, Dr. Eng.

Prof., Dept. of Architecture, Univ. of Tohoku, Dr. Eng. 
(1) 地域条件、利用条件及び経営条件に関わる各種パラメーターを設 定する。

(2) 経営計画として、各サービス利用者（以下、利用者）に設定され たサービス提供時間を満たしながら、1セット清4)当たりの延べ労 働時間 $T$ （延べ巡回回数 $Y$ ） を最小とするような介護拠点配置及 び巡回経路を求める。

(3) 最小化された延べ労働時間 $T$ （延べ巡回回数 $Y$ ) での、（必要） 従業員数 $A$ 及び (必要) 車輛台数 $V$ を求め、それらに基づいて総 費用 $C$ (人件費 $C L$ 、不動産儥借料 $C R$ 、車輌費関係 $C V$ 、その他の 支出 $C E$ ）を算出する。

(4) 利用者数 $N$ 及び提供サービス種類 $c_{k}$ から求められた総収入 $B$ と 総費用 $C$ の差を評価值（事業収支） $R$ とする。

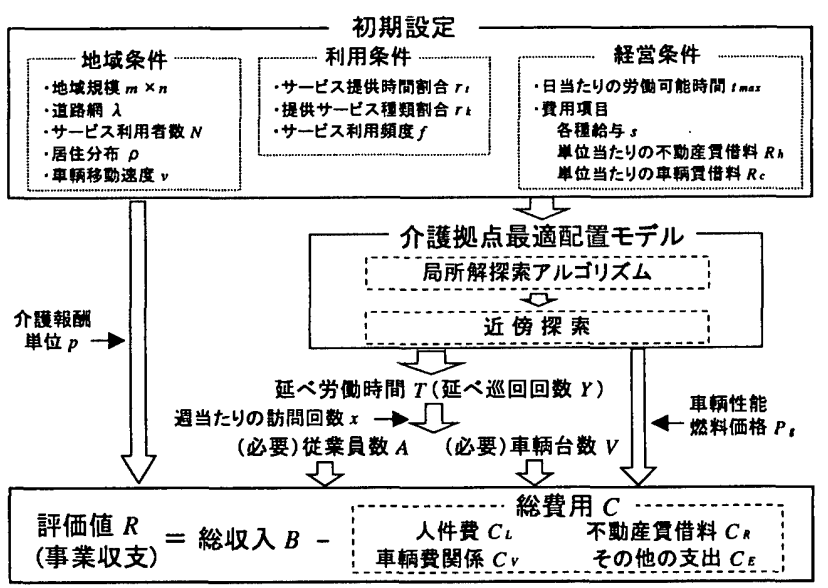

图 1 経営評価モデルの流れ

\section{2 各変数の考え方}

経営評価モデルに関わる各変数の概要を以下に示す。

- 従業員数 $A[$ [人] 及び車輛台数 $V$ [台]

（1）従業員数 : $A[$ 人]

従業員数 $A$ は、1 セット当たりの延べ巡回回数（日数） $Y$ 及び週 当たりの訪問回数 $x$ から年間の延べ巡回回数を求め、それを年間就 労日数 $(250$ 日) で除して求める。なお、小数点以下については、切 り上げるものとする。

$$
A=\frac{Y \cdot x \cdot 52}{250}
$$

介護保険で定められている訪問介護事業の人員基準は、管理者 1 名以上、サービス提供責任者 1 名以上（管理者との兼任も可）、従業 者（訪問介護員）は常勤換算で 2.5 名以上となっている。このような 条件のもとで人員配置計画を作成する場合、管理者、サービス提供 責任者及び常勤訪問介護員（以下、常勤職員）は必要最小限に抑え、 サービス供給計画に応じて柔軟に人員を配置できる非常勤訪問介護 員（以下、非常勤職員）をできるだけ確保することが人件費の面で は有利となる。

これから、本モデルでは、運営業務に支障をきたさない範囲で非 常勤職員をできるだけ多く配置することとし、管理者、常勤職員を 各 1 名、サービス提供責任者については所定の配置基淮を満たす最 少人員を配置し、残りの従業員を全て非常勤職員で賄うものと仮定 する。
（2）車輛台数: $V$ [台]

車輌台数 $V$ は、管理者数 $A_{m}$ を除いた従業員数と等しいものとする。

$$
V=A-A_{m}
$$

\section{- 人件費 $C_{L}$ [円/年 $]$}

人件費 $C_{L}$ は、㕍用形態別の人件費（管理者 $C_{m}$ 、サービス提供責任 者 $C_{c}$ 、常勤職員 $C_{f}$ 及び非常勤職員 $C_{p}$ ) の総和から成る。㕍用形態 別には、管理者、サービス提供責任者及び常勤職員については、そ れぞれの人員数（サービス提供責任者数 $A_{c}$ 、常勤職員数 $A_{f}$ ）に雇用 形態に応じた給与（月額／管理者 $S_{m}$ 、サービス提供責任者 $S_{c}$ 、常勤 職員 $S_{f}$ ）を乗じて足し合わせた月当たりの人件費に賞与（3 ヶ月分） 及び福利厚生費等 (20\%) を加味して求める。また、非常勤職員につ いては、延べ労働日数 $d_{p}$ に非常勤職員給与（時給） $S_{p}$ 及び日当たり の労働可能時間 $t_{\max }$ を乗じ、さらに交通費等（10\%）を加味して求め る。

$$
\begin{gathered}
C_{\iota}=C_{m}+C_{c}+C_{f}+C_{p} \\
=\left(A_{m} \cdot S_{m}+A_{c} \cdot S_{c}+A_{f} \cdot S_{f}\right) \cdot 15 \cdot 1.20+d_{p} \cdot S_{p} \cdot t_{\max } \cdot 1.10
\end{gathered}
$$

- 車輌費関係 $C V$ [円/年 $]$

車輭費関係 $C_{V}$ は、車輛賃借料 $C_{R c}$ 、駐車場賃借料 $C_{R p}$ 及び車輌然料 費 $C_{8}$ の総和から成る。

\section{- 車輛賃借料 $C_{\boldsymbol{R} c}$ [月/年 $]$}

車輛総数に 1 台当たりの車蟿賃借料 $R_{c}$ を乗じて求める。

. 駐車場貨借料 $C_{R p}$ [円/年］

車輛総数に 1 台当たりの駐車場賃借料 $R_{p}$ を乗じて求める。

\section{- 車輛燃料䚉 $C_{g}[$ 円 $/$ 年 $]$}

1 セット当たりの車輛然料費 $c_{g}$ と週当たりの訪問回数 $x$ に基づいて 算出する。

$$
\begin{aligned}
C_{V} & =C_{R c}+C_{R_{p}}+C_{R} \\
& =\left(V \cdot R_{c}+V \cdot R_{p}\right) \cdot 12+c_{g} \cdot x \cdot 52
\end{aligned}
$$

- 不動産貨借料 $C_{R}$ [円/年 $]$

不動産賃借料 $C_{R}$ は、固定的な必要床面積 $\left(20 \mathrm{~m}^{2}\right)$ と従業員数 $A$ に比例した床面積 $\left(3 \mathrm{~m}^{2} /\right.$ 人) を加えた総床面積に、単位当たりの不 動産賃借料 $R h$ を乗じて求める。

$$
C_{R}=(20+3 \cdot A) \cdot R_{h} \cdot 12
$$

- その他の支出 $C_{E}$ [円/年]

その他の支出 $C_{E}$ は、水道光熱費 $C_{w}$ 、通信費 $C_{n}$ 、広告宣伝費 $C_{a}$ 、 研修費 $C_{t}$ 、保険料 $C_{i}$ 、借入金支払利息 $C_{d}$ 及びその他運用経費 $C_{o}$ の 総和の年額から成る。

$$
C_{E}=\left(C_{w}+C_{n}+C_{a}+C_{t}+C_{i}+C_{d}+C_{o}\right) \cdot 12
$$

- 水道光熱費 $C_{w}$ [円/月 $]$

従業員数が 10 人までは固定費 $(20,000$ 円/月）とし、11 人以上で は固定費に従業員の超過員数に比例した費用（800 円/人・月）を加え る。

$$
\begin{aligned}
& \cdot A \leqq 10 \text { の場合 } \\
& \qquad C_{w}=20,000
\end{aligned}
$$

$\cdot A>10$ の場合

$$
C_{w}=20,000+800 \cdot(A-10)
$$

- 通信費 $C_{n}$ [円/月］

固定費 $(20,000$ 円/月）に従業員数 $A$ に比例した費用（3,000 円/人・ 月）を加える。

$$
C_{n}=20,000+3,000 \cdot A
$$


- 広告宣伝費 $\boldsymbol{C}_{\boldsymbol{a}}$ [円/月］

従業員数に関倸なく、固定費（50,000 円/月）とする。

$$
C_{a}=50,000
$$

- 研修費 $C_{t}$ [円/月］

非常勤職員数 $A_{p}$ に比例（6,000 円/人・月）する。

$$
C_{,}=6,000 \cdot A_{p}
$$

- 保険料 $C_{i}$ [円/月］

従業員数 $A$ に比例（1,500 円/人・月）する。

$$
C_{1}=1,500 \cdot A
$$

- 借入金支払利息 $\boldsymbol{C}_{\boldsymbol{d}}$ [円/月］

初期投資（事業所敷金、介護報酬末受給期間の運転資金利息分及 びその他の費用) に伴う借入金支払利息は、定額法（50,000 円/月） によって返済していくものとする注5)。

$$
C_{d}=50,000
$$

- その他運用経費 $C_{\boldsymbol{o}}[$ [円/月 $]$

従業員数 $A$ に比例 $(2,000$ 円/人・月）する。

$$
C_{o}=2,000 \cdot A
$$

\section{- 総収入 $B$ [月/年 $]$}

本モデルで想定する収入項目は、サービス提供によって生じる介 護報酬のみである。従って、総収入 (介護報酬) $B$ は、提供サービス の種類、サービス提供時間に応じた介護報酬単位 $p_{i} に 、 1$ 単位当たり 10 円で換算して算出する。

$$
B=10 \cdot \sum_{i=1}^{N} p_{i} \cdot x \cdot 52
$$

- 総費用 $C$ [円/年 $]$

総費用 $C$ は、人件費 $C_{L}$ 、車䡕費関係 $C v$ 、不動産賃借料 $C_{R}$ 、その 他の支出 $C_{E}$ の総和から成る。

$$
C=C_{L}+C_{V}+C_{R}^{\prime}+C_{E}
$$

\section{- 評価値（事業収支） $R$ [円/年]}

評価值（事業収支） $R$ は、総収入 $B$ から総費用 $C$ を差し引いたも のとする。

$$
R=B-C
$$

\section{3 介護拠点最適配置モデル}

\section{- 介護拠点最適配置モデルの考え方}

事業主体は、仮想地域内に介護拠点（事業所）を設置し、そこか ら利用者宅を巡回し、サービスを提供していくものと考える。 介護拠点最適配置モデルの基本的な考え方を以下に示す。

- 訪問介護員は、日当たりの労働可能時間 $t_{\text {max }}$ 内に、「(1)次の利用者 宅を訪問し、(2)利用者に応じた介護サービスを提供し、(3)介護拠 点に戻ってくる」ことがいずれの地点を訪問してもできなくなっ た時点で、介護拠点へ戻ってくるものとする。

・車輛での移動は、道路網によって設定された所定の道路でのみ可 能とし、二地点間の移動経路は、ダイクストラのアルゴリズム影 6)を用いて予め求めた最短路によるものとする。なお、同一メッ シュ内での移動時間は考慮せず、同一メッシュに居住する利用者 は、便宜上、メッシュの中心に集中して居住しているものと考え る。

\section{- 評価関数}

ここでの最適基準の考え方は、利用者全員にサービス提供を行う までの延べ労働時間 $T$ （延べ巡回回数 $Y$ ）を最小とするように介護
拠点及び巡回経路を決定するものである。

具体的には、利用者数 $N$ の地域において、介護拠点 $(X, Y)$ での、 $i$ 回目の巡回に要する移動時間を $t_{m i}$ 、サービス提供時間を $t_{c i}$ 、事務時 間を $t_{d i}$ とすると、その時の労働時間 $t_{i}$ は、 $t_{i}=t_{m i}+t_{c i}+t_{d i}$ で表される (時間制約条件 $: t_{\text {max }} \geqq t_{i}$ )。最終的に利用者 $N$ 人に対して $r$ 回の巡回 を行う $(N \geqq r)$ とすると、評価関数 $Q_{(x, n) \text { は、 }}$

$$
\begin{aligned}
Q_{(x, y)} & =\sum_{i=1}^{r} t_{i} \\
& =\sum_{i=1}^{r}\left(t_{t=1}+t_{c t}+t_{d i}\right)
\end{aligned}
$$

となり、これを最小化することを目指し、この評価関数を全地点に ついて逐次計算し、その中で評価関数の最小值神》を与える介護执点 $\left(X_{\min }, Y_{\min }\right)$ 及び巡回経路を最適解とする。

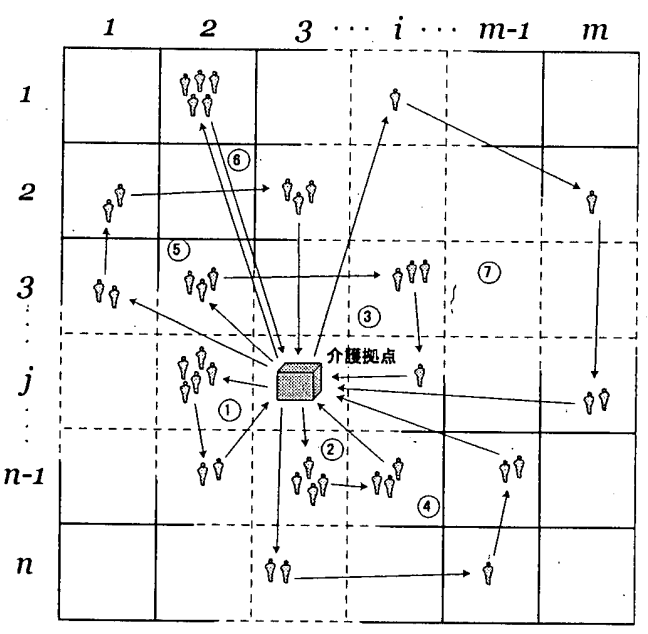

図 2 巡回経路のイメージ

\section{- 局所解探索アルゴリズムと近傍探索処理}

上記のような巡回経路問題は、一般に大域的最適解を求めること は困難であり、近似解で代用していくこととなる。近似解を探索す るための手法はいくつか開発されているが、本研究では、探索の効 率性に比較的優れ、少ない計算量である程度合理的な解に到達でき ると思われる局所解探索アルゴリズムを採用する。具体的には、利 用者宅を巡回する際の訪問順序について、現在地点から移動可能な 末訪問地点が複数箇所ある場合に、利用者数が最大となる未訪問地 点を選択することとし、時間制約条件を満たす限りこれを絽り返す ものである。これは 1 巡回当たりの利用者数の最大化を目指したも のであり、ある程度合理的な巡回経路に到達するものと考えられる が、利用者の居住分布状況が全体的または局所的に分散している場 合や未訪問地点が少なくなった場合等においては、非効率な巡回経 路となる可能性が高い。そこで、本モデルでは、局所解の精度を高 めるために、上記のアルゴリズムで得られた局所解に対し巡回経路 を確率的に入れ替える近傍探索処理を実行し、最終的に得られた解 を最適解と見なすこととする。具体的には、遺伝的アルゴリズムで 用いられる突然変異処理の考え方を採用し、巡回経路に従って並へ た地点番号を遺伝子コードとして、遺伝子座（地点番号）の確率的 な入れ替えを行い、評価值が更新された場合に新たな巡回経路に移、 行することで、より合理的な解に近づけていくものである。 


\section{3. 基本モデルの経営評価分析}

ここでは、経営評価基本モデルを用いて仮想地域を対象とした 100 回のシミュレーションを行い全結果について分析した後、事業収支 の第一四分位点を標淮モデルとして抽出して詳細な分析を行う。な お、基本モデルでの仮定とパラメーター設定部妾以下に示す。

・利用者は、シミュレーション毎に適当に設定された 3 種の 2 次元 正規分布の重ね合わせた構成比によって仮想地域内のメッシュ に配置する。

・仮想地域内の道路は、全てのメッシュを通るように、単位メッシ ュピッチで碁盤目状に配する。

表 1 基本モデルのパラメーター設定

\begin{tabular}{|c|c|c|c|c|c|c|}
\hline \multirow{2}{*}{\multicolumn{2}{|c|}{ 種類 }} & \multirow{2}{*}{ 単位 } & \multicolumn{2}{|c|}{ パラメーター設定 } & \multirow{2}{*}{ ステッップ幅 } & \multirow{2}{*}{ 摆隼值 } \\
\hline & & & 状熋 & 設定值 & & \\
\hline \multicolumn{2}{|r|}{ 地域規掑 } & {$[\mathrm{km} \times \mathrm{km}]$} & 固定 & 椤準值 & - & $20 \times 20$ \\
\hline \multicolumn{2}{|r|}{ 利用者数 } & [人] & 変動 & 楫璋值 & - & 100 \\
\hline \multicolumn{2}{|c|}{ 利用者磪得割合 } & {$[\mathrm{x}]$} & 固定 & 椤㔼值 & - & $100 x$ \\
\hline \multicolumn{2}{|r|}{ 居住分布状涗 } & {$[-]$} & 変動 & - & - & \\
\hline \multicolumn{2}{|r|}{ 新問回数 } & [回/通 $]$ & 变動 & $1 \sim 7$ & 1 & 3 \\
\hline \multicolumn{2}{|c|}{ 特別地域加算係数 } & {$[-]$} & 固定 & 楼準值 & - & 1.00 \\
\hline \multirow{3}{*}{ 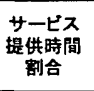 } & 0.5時問末满 (0.5時湖) & {$[\mathrm{x}]$} & 固定 & 栵篗值 & - & $18.2 x$ \\
\hline & $0.5 \sim 1.0$ 時间 (1.0时时) & {$[x]$} & 固定 & 椤準値 & - & $35.1 x$ \\
\hline & 1.0時闻以上 $(1.5$ 時田 $)$ & {$[x]$} & 固定 & 罾隼值 & - & $46.7 x$ \\
\hline \multirow{3}{*}{$\begin{array}{c}\text { 提佛 } \\
\text { サ达 } \\
\text { 割合 }\end{array}$} & 身本介算中心 & {$[\mathrm{x}]$} & 固定 & 橙隼值 & - & $35.0 x$ \\
\hline & 生活摄助中心 & {$[x]$} & 固定 & 棬毞值 & - & $39.4 x$ \\
\hline & 粗み合わせ & {$[\mathbf{x}]$} & 固定 & 楱隼值 & - & $25.6 x$ \\
\hline \multicolumn{2}{|r|}{ 管理者 } & [万円/月] & 固定 & 楞準值 & - & 24.0 \\
\hline \multicolumn{2}{|c|}{ サービス提供青任者 } & [万円/月] & 固定 & 摆準值 & - & 20.0 \\
\hline \multicolumn{2}{|c|}{ 常勤勘間介港頁 } & [万円/月] & 固定 & 根準值 & - & 18.0 \\
\hline \multicolumn{2}{|c|}{ 非常勤乵間介睡頁給与 } & [円/時 $]$ & 固定 & 检準值 & - & 1.500 \\
\hline \multicolumn{2}{|c|}{ 労佰可能時間 } & [時/日] & 固定 & 㮛準值 & - & 7 \\
\hline \multicolumn{2}{|r|}{ 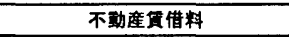 } & 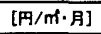 & 固定 & 模隼值 & - & 2,000 \\
\hline \multicolumn{2}{|r|}{ 車辆移栜速度 } & [km/時] & 固定 & 樶篗值 & - & 30 \\
\hline
\end{tabular}

\section{1 居住分布状況と事業収支の関係}

全シミュレーション結果を見ると、事業収支にばらつきが認めら れ、訪問回数 3 回での差額は最大で年間約 860 万円となっている。 シミュレーション毎に確率的に利用者分布を設定していることから、 ここでの事業収支のばらつきは、利用者の居住分布状況の差によっ て生じているものと考えられる。即ち、居住分布状況に基づく移動 効率性の差によって、事業収支が数百万円程度上下することが分か る。

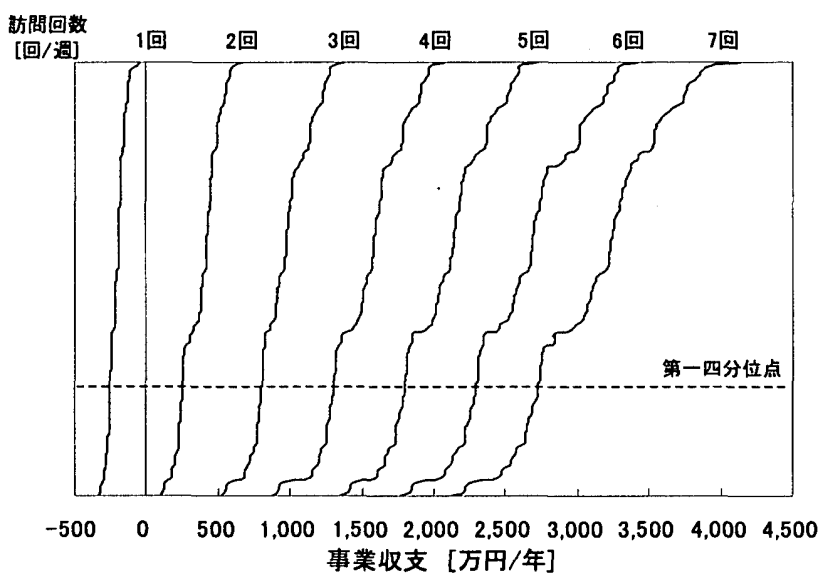

図 3 事業収支結果（試行回数 100 回）

\section{2 標準モデルの経営評価分析}

\section{- 収支構造}

費科目別構成比は、人件費割合が $80 \%$ 近くに達し、中でも非常勤 職員給与がそのうちの大半を占めている。在宅サービスの事業収入 は、介護報酬のみによっていることから、事業収支を向上させるに は、費用の大半を占める人件費（特に非常勤職員給与）をいかに制 御するかが重要な要件になると言える。
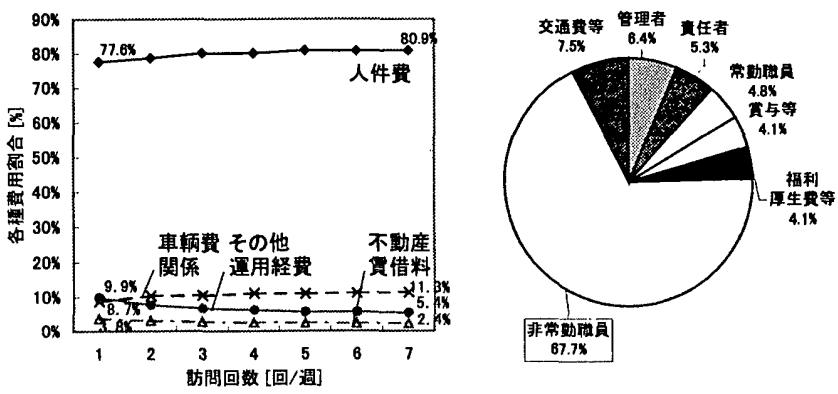

図 4 費科目別構成比（左 : 全体/右 : 人件費内訳 [訪問回数 3 回]）

\section{- 詳細分析}

介護拠点を仮想地域モデル内の全地点に逐次配置した場合の事業 収支（訪問回数 3 回=標淮訪問回数）を降順で並び替えると、収支 が(1)〜(5)までの 5 種の範囲に大別でき、順に延べ巡回回数及び従業 員数が 1 単位ずつ減少している部)ことが分かる。これは、延べ巡回 回数の減少が概ね従業員数の減少となり、200〜250 万円程度の人件 費の削減につながったためと言える。一方、移動効率性（介護拠点 配置）の向上が延べ巡回回数の減少につながらない場合には、車輛 燃料費等の削減効果しか期待できず、事業収支は僅かな増加に留ま っている。

以上より、介護拠点の配置場所は延べ巡回回数が最小となる地点 であれば周辺環境や利便性等を考慮して配置場所を決定しても事業 収支への影響は小さいと言える。

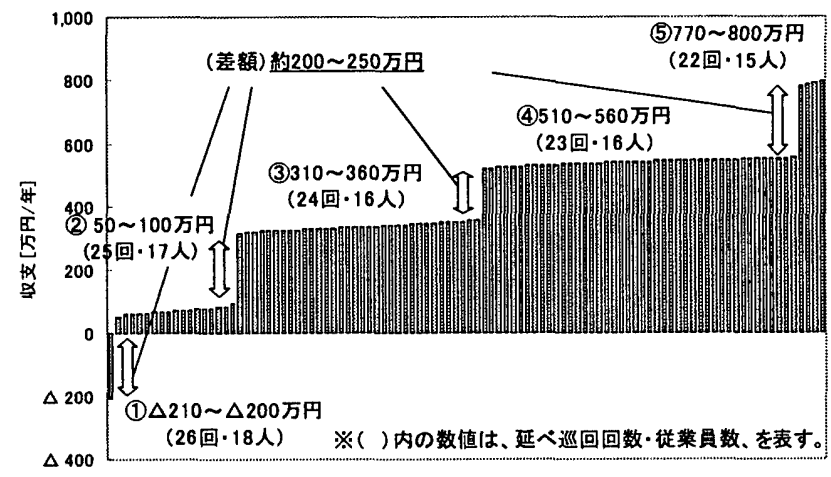

图 5 地点別事業収支（降順並び替え［訪問回数 3 回]）

\section{3 地域規模及び利用者数と事業収支の関係}

ここでは、基本モデルにおいて地域規模と利用者数をそれぞれ変 化させて事業収支との関係を分析する。なお、いずれもステップ幅 毎に 50 回の試行を行っており、その時の事業収支の第一四分位点を 抽出している。 
まず、訪問回数別の地域規模と事業収支の関係を見ると、事業収 支が同一となる点を結んだ曲線（等事業収支曲線）は訪問回数とと ともに概ねなだらかに上昇し、損益分岐線は、いずれの地域規模に おいても訪問回数が 1〜2回の間に収まっていることから、地域規模 に関係なく、㕫問回数 1 回の場合にのみ収支が負となり、2 回以上で 注収支が正となることが分かる。これより、地域規模が $30 \mathrm{~km} \times 30$ $\mathrm{km}$ 程度の範囲内では、地域規模に対する事業収支の変化率は比較的 小さく、事業展開範囲の大きさは事業収支を大きく左右する要因に はならないと言える。一方、訪問回数別の利用者数と事業収支の関 係については、等事業収支曲線が原点に対して概ね凸の形状を有し ており、利用者数に対する事業収支の賕化率注、利用者数の減少に 従って徐々に大きくなり、特に利用者数がある一定人数以下となる と、事業収支が大きく変動することが分かる。なお、標準訪問回数 で収支が 0 万円となる利用者数（標帮限界利用者数）は約 53 人であ り、利用者数がこれを下回ると、標準的な条件の下では採算の確保 が見込めない状況にある。

以上より、地域規模が極端に大きくない限り、利用者の絶対数が 事業の採算性を決定づける大きな要因となっていると言える。

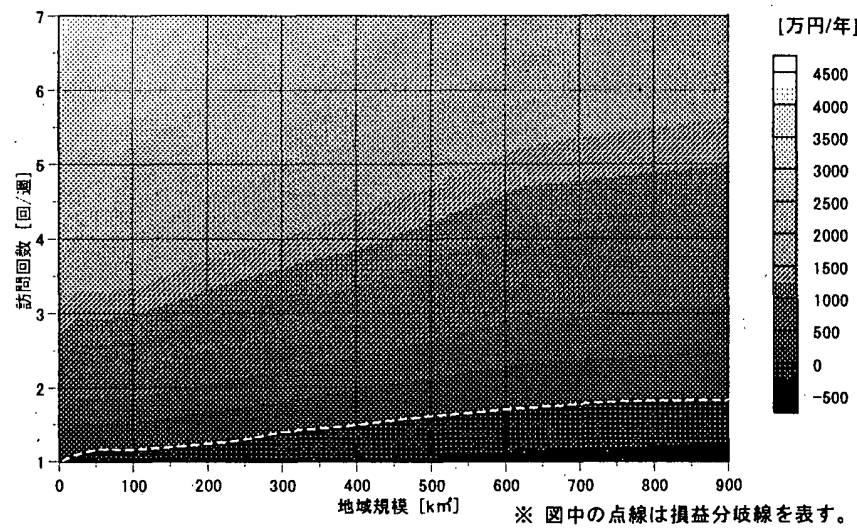

図 6 地域規模と事業収支の関係

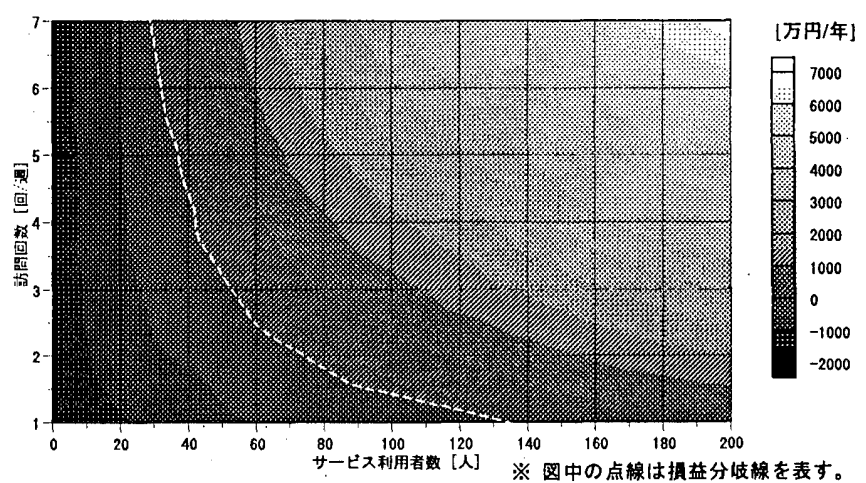

図 7 サービス利用者数と事業収支の関係

\section{4. 感度分析}

ここでは、標準モデルにおいて各種パラメーターを変化させて行 った感度分析の結果について述べる。

\section{1 サービス提供時間割合別事業収支}

サービス提供時間割合と事業収支の関係を考えると、収入の面で は、提供時間の長いものほど訪問回数 1 回当たりの介護報酬が高く なり、収支にはプラスに作用する。'その一方、費用面では、提供時
間が長くなるほど 1 セット当たりの延べ巡回回数が增加し、それに 伴い人件費等の費用が増大して収支にはマイナスに働く。

実際に、標淮訪問回数でのサービス提供時間と事業収支の関保を 見ると、提供時間を全て 1.5 時閒とする場合に事業収支が最大となる。 また、提共時間を全て 1.5 時間とできない場合には、できる限り 1.5 時間とし、残りについては 0.5 時間割合をできるだけ高めることが事 業収支の面では効率的となる。即ち、利用者のニーズに応じながら、 時間的なめりはりをつけたサービス提供を行うことが採算性の面か らは望ましいと言える。

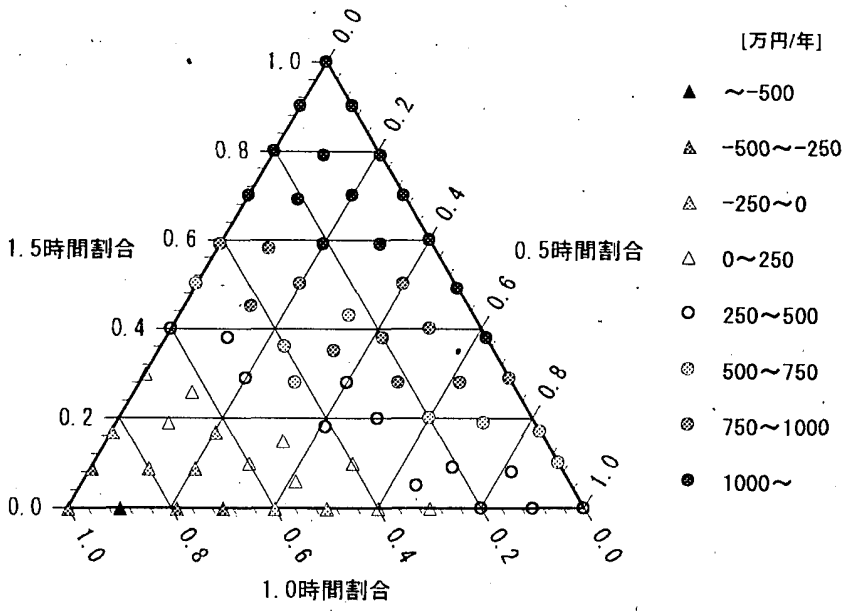

図 8 サービス提供時間割合と事業収支の関係（訪問回数 3 回）

\section{2 非常勤職員給与別事業収支}

全体の傾向を見ると、時給の増加に対して等事業収支曲線は指数 関数的に上昇している。損益分岐線の推移を見ると、標準訪問回数 で収支が 0 万円となる給与（標準限界給与）は時給約 1,850 円で、そ れ以降は損益分岐線が急上昇し、時給 2,000 円強からは毎日訪問して も採算が確保できない状況となる。

以上より、標準限界給与前後からの事業収支の変化率が大きい範 进では、給与（時給）のわずかな変化で収支が大きく左右されるこ とから、実際の事業経営では、標準限界給与以下で、ある程度余裕 を持った給与設定が望ましいと言える。

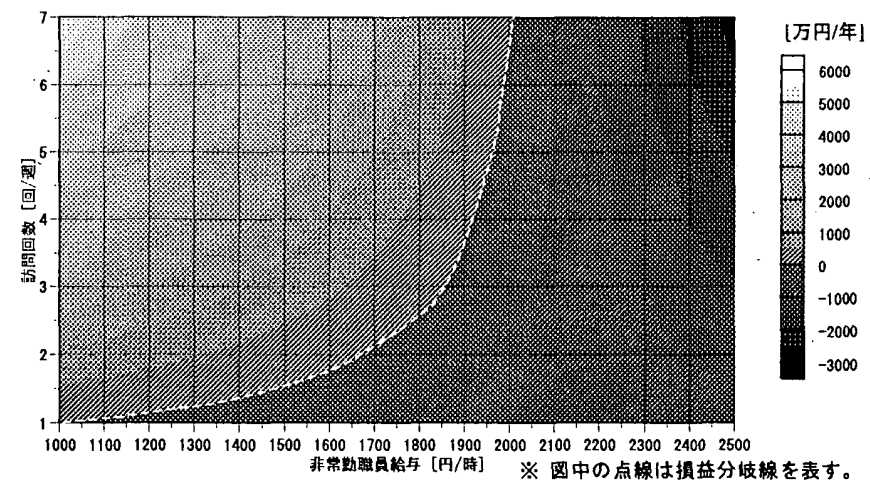

图 9 非常勤職員給与と事業収支の関倸

\section{3 不動産貨借料別事業収支}

不動産賃借料と事業収支の関係を見ると、等事業収支曲線はゆる 
やかな傾きで直線的に伸びており、剠問回数が 2 回以上であれば、 不動産賃借料に関倸なく採算を確保できる見通しとなっている。こ れより、不動産賃借料は一般には収支に大きく影響しないと言える。

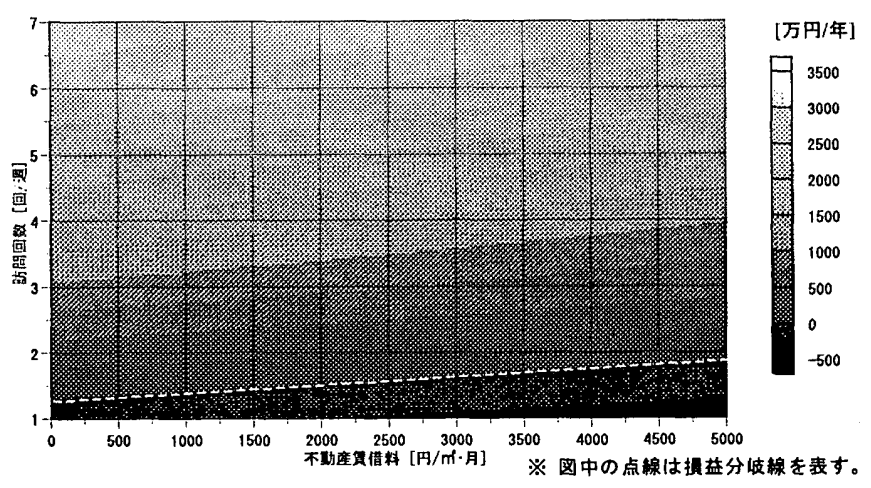

図 10 不動産賃借料と事業収支の関係

\section{4 車轌移動速度別事業収支}

車輛移動速度に対寸る事業収支の変化率は、移動速度が $20[\mathrm{~km} /$ 時]程度から小さくなるに従って急激に大きくなる一方、移動速度 30 [kn/時] 程度からは、事業収支の変化率が小さくなり、事業収支 がほほ一定となる範囲も見られる。これは、移動速度が大きくなる ほど、(1 巡回当たりの総労働時間に占める) 移動時間割合の変化率 が小さくなり、巡回効率性に影響しなくなるためであると考えられ る。これより、交通量等の影響により平均移動速度が下がる地域で の事業経営では、移動速度のわずかな変動によって収支状況が大き く変化する可能性があると言える。

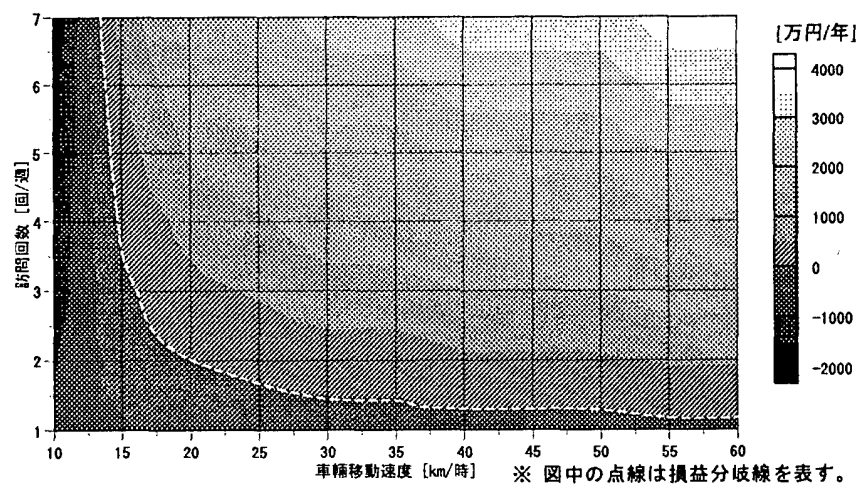

図 11 車軜移動速度と事業収支の関倸

\section{5. 宮城県内市町村における事業探算性}

5. 1 ケーススタディ

ここでは、県内 71 市町村のうちで採算を確保できない可能性が高 いと推測される農村地域及び漁村地域から計 6 町 (牡鹿町・蔵王町・ 七ケ宿町・東和町・鳴子町・丸森町）をモデル地区に選定し、実際 の道路網と高路者数のメッシュデータ流10)を用いてケーススタディ を行った。モデル地区の概要は、表 2 に示寸通りである。

\section{- 午ーススタディ結果}

ケーススタディから、牡鹿町と七ケ宿町では採算の確保が難しい 状況にある一方、その他 4 町では概祆採算を確保できる見通しとな った。
表 2 モデル地区の概要

\begin{tabular}{|c|c|c|c|c|c|}
\hline $\begin{array}{l}\text { モデル } \\
\text { 地区 }\end{array}$ & \begin{tabular}{|c|} 
슴 \\
(H122⿴囗玉 \\
{$[$ 서 }
\end{tabular} & $\begin{array}{c}\text { 高龄化率 } \\
\text { [\%] }\end{array}$ & 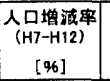 & $\begin{array}{c}\text { 嗮面稍 } \\
\left.\text { [ } \mathrm{m}^{\prime}\right]\end{array}$ & 地域特性等 \\
\hline 牡㢕町 & 5,279 & $33.4 x$ & $\Delta 10.4 \mathrm{x}$ & 73.0 & 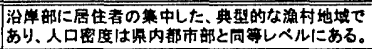 \\
\hline 蔵王町 & 13,545 & $23.8 \times$ & $\Delta 2.7 \mathrm{x}$ & 152.9 & 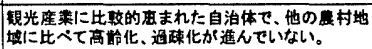 \\
\hline 七ヶ宿町 & 2,034 & $36.6 x$ & $\Delta 6.4 x$ & 263.0 & 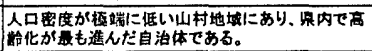 \\
\hline 東和町 & 8,718 & $30.2 x$ & $\Delta 6.4 \mathrm{X}$ & 140.8 & 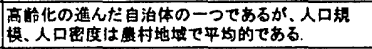 \\
\hline 鲒子町 & 9.289 & $29.3 \mathrm{x}$ & $\Delta 8.8 \mathrm{x}$ & 326.1 & 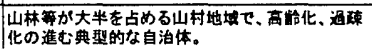 \\
\hline 丸森町 & 17,868 & $28.8 \times$ & $\Delta 5.7 \mathrm{X}$ & 273.3 & 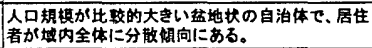 \\
\hline
\end{tabular}

表 3 モデル地区別経営評価分析結果

\begin{tabular}{|c|c|c|c|c|c|}
\hline $\begin{array}{l}\text { モテル } \\
\text { 地区 }\end{array}$ & 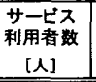 & 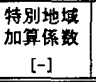 & $\begin{array}{c}\text { 収支 } \\
\text { [万円/年 }]\end{array}$ & 状況 & $17 x^{2}$ \\
\hline 恃䴠町 & 60 & 1.000 & 252.4 & 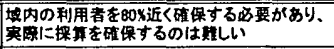 & x. \\
\hline 被王町 & 122 & 1.000 & $1,478.7$ & 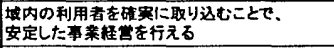 & 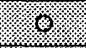 \\
\hline 七ヶ宿町 & 28 & 1.150 & $\Delta 126.3$ & 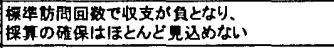 & $x$ \\
\hline 果和町 & 89 & 1.061 & $1,515.3$ & 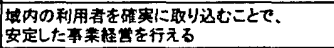 & 10. \\
\hline 啲子町 & 102 & 1.081 & $1,570.8$ & 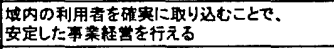 & 6 \\
\hline 丸森町 & 183 & 1.023 & $2,812.5$ & 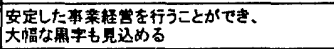 & 8 \\
\hline
\end{tabular}

また、各モデル地区の事業収支部11)（実収支）と図 7 で各モデル地 区の利用者数を対応させて得られた推定值を比較すると、両者の間 には大きな開きがなく、差額が 50〜300 万円程度に収まっているこ とから、仮想地域での推定値を実際の市町村等での大まかな経営評 価值（事業収支）として見なせることが分かった。これより、事業 展開地域の総利用者数が把握できれば、当該地域での事業採算性を 大まかには判断できると考えられる。

表 4 モデル地区別の推定值と実収支の比較

\begin{tabular}{|c|c|c|c|c|c|}
\hline \multirow[b]{2}{*}{ モデル地区 } & \multirow{2}{*}{$\begin{array}{c}\text { サービス } \\
\text { 利用者数 } \\
\text { [人] }\end{array}$} & \multirow{2}{*}{$\begin{array}{c}\text { 特別地域 } \\
\text { 加算係数 } \\
{[-]} \\
\end{array}$} & \multicolumn{2}{|c|}{ 事業収支 } & \multirow{2}{*}{ 1. } \\
\hline & & & $\begin{array}{l}\text { (1) 推定值 } \\
\text { [万枵/年] }\end{array}$ & $\begin{array}{l}\text { (2) 実収支 } \\
\text { [万円/年] }\end{array}$ & \\
\hline 牡鹿町 & 60 & 1.000 & 150 & 262 & 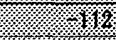 \\
\hline 蔵王町 & 122 & 1.000 & 1,250 & 1,479 & 稱 \\
\hline 七ヶ宿町 & 28 & 1.150 & $\triangle 450$ & $\triangle 382$ & , \\
\hline 東和町 & 99 & 1.061 & 850 & 1,131 & 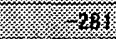 \\
\hline 腝子町 & 102 & 1.091 & 900 & 988 & . \\
\hline 丸森町 & 193 & 1.023 & 2,480 & 2,530 & 20 \\
\hline
\end{tabular}

\section{2 市町村別の事業採算性の推定}

\section{・地域における在宅サービスの供給可能性}

以上を踏まえ、宮城県内 71 市町村を対象に、市町村を単位とした 場合の各自治体での事業採算性を総利用者数に基づいて検討した。 なお、3.3での結果では標準限界利用者数が約 53 人となっているが、 実收支が推定值をやや上回っていることを考虑し、ここでは利用者 数 50 人を推定標準限界利用者数とし、利用者数 50 人を下回る場合 に採算を確保できないものと考える。また、利用者獾得割合は、50\% 及び $100 \% の 2$ 種類を設定して検討する。

その結果を見ると、利用者獲得割合を $100 \%$ と設定した場合には、 七ヶ宿町や北上町など計 7 町村、利用者獾得割合を $50 \%$ とした場合 
は、川崎町や唐桑町など計 29 町村で採算の確保が見込めない状況と なる。これらの自治体を見ると、総面積が $150 \mathrm{k} \mathrm{n}$ をを越える比較的規 模の大きい山間部の自治体（七ヶ宿町・花山村等）と総面積 $70 \mathrm{k} \mathrm{m}$ 未満の規模の小さい自治体 (高清水町・瀬峰町等) とに大別できる。 前者は、過疎化等の影響により、域内の推定サービス利用者の絶対 数が標準限界利用者数を下回ったと考えられ、後者は、総面積・人 口規模とも小さいことの影響が大きいと推測される。その一方、都 市部等の高齢者が一定程度居住している自治体では、利用者を着実 に確保できれば、採算を十分確保できることが分かる。

地域における在宅サービス（訪問介護）の供給を考えた場合、都 市部等の採算の確保が見込める地域では、民閒事業者の参入も十分 見込めるとともに、行政側の財政面での負担も特に問題にはならな いと考えられる。他方、過疎化の進んだ山間部等の採算の確保が見 込めない地域では、標淮的な条件の下では民間事業者の参入が見込 めない状況にあり、当該市町村の公的機関等が慢性的な赤字を抱え ながら在宅サービスを実施せざるを得ない状況になっていると推測 される。
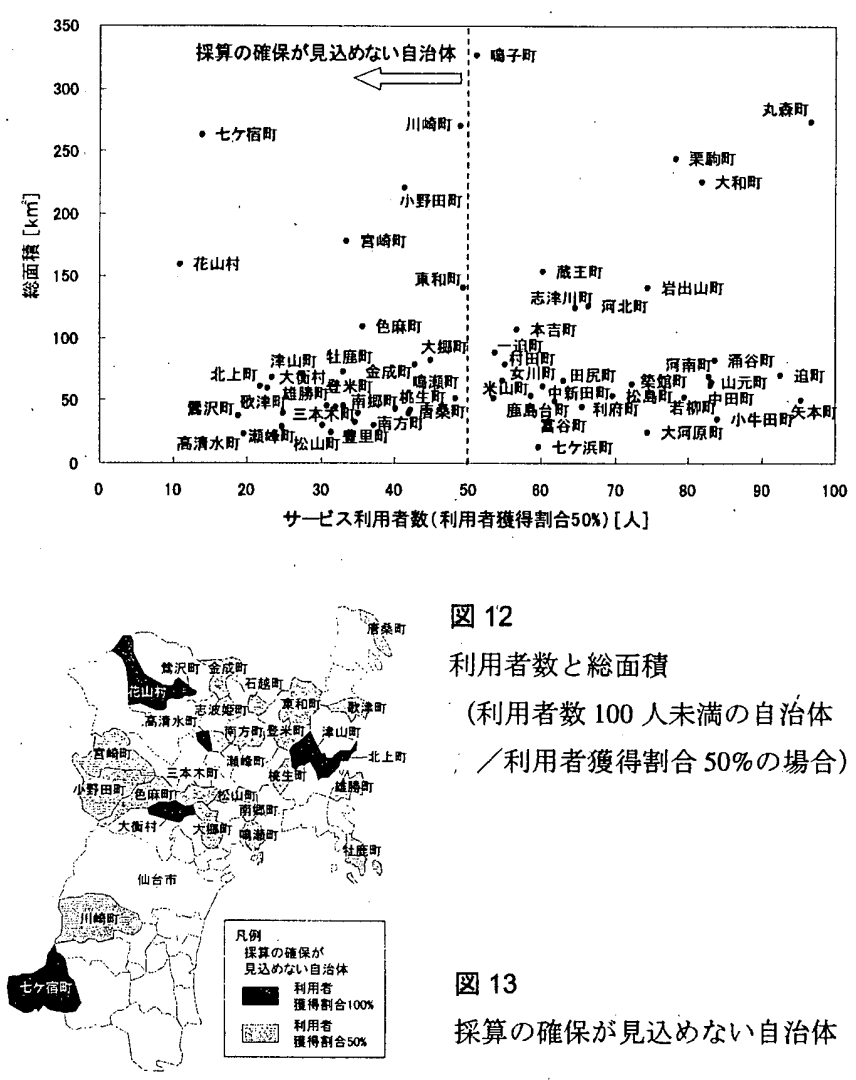

図 12

利用者数と総面積

(利用者数 100 人未満の自治体 /利用者獲得割合 $50 \%$ の場合)

図 13

採算の確保が見込めない自治体

\section{6. 結論}

本研究では、在宅サービス事業主体の経営評価モデルを作成し、 仮想地域でのシミュレーションを行った。その結果より、在宅サー ビスの事業特性を地域条件からみると、利用者の絶対数及び居住分 布状況が事業採算性を決定づける主な要因となっていることが分か うた。また、宮城県内市町村別における事業採算性の検討から、採 算を顧保することが難しいと見込まれる自治体が山間部を中心に認 められた。

・今後の在宅サービスの在り方
以上の結果を踏まえ、ここでは、採算の確保が見込めない地域で の在宅サービスの在り方について考察する。

\section{·広域連携}

前述の通り、事業採算性は域内利用者の絶対数に大きく依存し、 地域規模（事業展開範囲）の影響は比較的小さい。この事業特性を 考虑した場合、標準限界利用者数を割り込み、採算の確保が見込め ない自治体であっても、隣接する周辺自治体と連携することで、採 算を確保できる可能性がある。即ち、在宅サービスを市町村を越え た範囲で考えることで、供給側の財政的な負担を增すことなく、多 くの高齢者が自宅で介護を受けられることとなる。

\section{- 集積化}

また、シミュレーションの結果から、利用者の居住分布状況の変 化によって、事業収支が数百万円程度の幅で上下寸ることが判明し た。従って、域内に分散する居住者を一定の範囲に集積することで 収支状況の改善が期待できる。具体的には、既存ストック（空家や 小学校等）の活用等により、新規建設コスト等の追加的費用の抑制 を図りながら、(1)近隣の一定の範囲に利用者を移住させることで「在 宅」を維持しながら利用者の集積化を図る「近居型」、(2)自宅から近 隣のサービス提供拠点まで送迎してもらい、そこで介護サービスを 受ける通所介謏（デイサービス）に近い「通所型」、(3)利用者が最 も集積することとなる「施設型」、等の方法が考えられる。しかし、 (2)、(3)は在宅」という概念からやや離反するとも言え、(1)につい ても利用者によっては住み慣れた住宅からの移転による環境移行 の問題を生ずる懸念がある。一般に「在宅の確保」と「事業採算性」 との間にトレードオフの関係がある場合には、その解決の方向は地 域によって異なると考えられるが、いずれにしても各自治体が地域 の実情を踏まえて、「在宅」の概念、地域づくりの方向、財政面で の負担等の観点から介護サービスメニューの多面的な検討を行い、 地域特性に応じたサービス提供システムを構成していく必要があ ると考光られる。

\section{参考文献}

1) 青柾人：成助する介護ビジネスの起こし方・運営一划、日本实業出版 社、2003

2）奥村晴彦：C言語による最新アルゴリズム事典、技術評諭杜、1991

3）宦城県企画部統訃課：宮城県地域メッシュ統計の概要（伻成７年度国勢 調盗編)、2000

歖

1）介護保険制度では、「居宅サービス」と定義されている。

2）砬問介謢とは、訪問介護員（ホームヘルパー）等が利用者の居笔を垓問 し、人浴、排泄、食事等の介謢、その他の日常生活上の世話を行う介護サ一 ビスのことで、利用者の身体に直接接触して行う「身体介護」と摜除・沫濯 · 調理等の日常生活の援助を行う「生活授助」の2 種類が定められており、そ れぞれ提詣洔間に応じて介護報酬监位が定められている。

3）但し、ターススタディでは、特别地域指定区域が含まれるモデル地区に ついては特別地域加算を行う。

4）1 セットとは、利用者全員にサービス提供を 1 回行うことを言う。

5) 参考文献 1) を参热。

6) 至考文献 2) を参照。

7 ）延べ労働時間 $T$ （延べ巡回回数 $Y ）$ が等しい場合には、延べ移動咭間 $T_{m}$ の小さい介護起点を採用し、最適解とする。

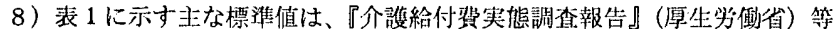
の奏際のデータを用いて算出した。

9) (3)と(4)については、従業買数は等しい。

10）参考文献 3）を参照。

11）ここでの事業収支は、特别地域㞦算を考鹤しないものとする。

（2004年 4 月16日原稿受理，2004年 7 月15日採用決定） 